\title{
Support for Radical Left Ideologies Among Youth in Switzerland ${ }^{1}$
}

\author{
Cédric Jacot*, Dirk Baier**, Sandrine Haymoz ${ }^{* *}$, Anna Isenhardt ${ }^{* * * *}$, \\ Maria Kamenowski* ${ }^{*}$, and Patrik Manzoni**
}

Abstract: This article aims to better understand the determinants which support the ideologies of the Radical Left among young people in Switzerland. The analyses presented in the article are based on a survey on the theme of political radicalism which has been carried out in secondary schools on level II. The findings showed that economic and political deprivation, as well as a high degree of anti-authoritarianism, increase the probability of adhering to the different ideologies of the Radical Left. They also suggest that several aspects of the school context have an impact on the ideological positioning of young people.

Keywords: Anti-capitalism, communism, no-border, radical left, youth

\section{Adhésion aux idéologies de la gauche radicale parmi les jeunes en Suisse}

Résumé: Cet article vise à mieux comprendre les déterminants de l'adhésion aux idéologies de la gauche radicale chez les jeunes en Suisse. Les analyses présentées dans l'article sont basées sur une enquête sur le thème du radicalisme politique menée dans les écoles du secondaires II. Les résultats montrent que le fait d'être économiquement et politiquement défavorisé et un anti-autoritarisme élevé augmentent la probabilité d'adhérer aux différentes idéologies de la gauche radicale. Ils suggèrent également que plusieurs aspects du contexte scolaire ont un impact sur le positionnement idéologique des jeunes.

Mot-clés: anticapitalisme, communisme, idéologie sans frontières, gauche radicale, jeunes

\section{Befürwortung linksradikaler Ideologien unter Jugendlichen in der Schweiz}

Zusammenfassung: Der Beitrag untersucht die Einflussfaktoren linksradikaler Ideologien unter Jugendlichen in der Schweiz. Die im Beitrag vorgestellten Analysen basieren auf einer schweizweiten Befragung zum Thema politischer Extremismus, die in den Sekundarschulen II durchgeführt wurde. Die Ergebnisse zeigen, dass eine ökonomische Benachteiligung, politische Deprivation und Antiautoritarismus die Wahrscheinlichkeit erhöhen, dass den verschiedenen ideologischen Dimensionen verstärkt zugestimmt wird. Zusätzlich weisen die Analysen darauf hin, dass verschiedene Faktoren des Schulkontextes einen Einfluss auf die Zustimmung zu linksradikalen Ideologien haben.

Schlüsselwörter: Antikapitalismus, Kommunismus, No-Border-Orientierung, radikale Linke, Jugendliche

\footnotetext{
* University of Fribourg, Domaine des sciences des sociétés, des cultures et des religions, $\mathrm{CH}-1700$ Fribourg, cedric.jacot@unifr.ch

** Zurich University of Applied Science, Department of Social Work, Institute of Delinquency and Crime Prevention, CH-8037 Zurich, dirk.baier@zhaw.ch, maria.kamenowski@zhaw.ch and patrik.manzoni@zhaw.ch

*** University of Applied Sciences and Arts Western Switzerland - HES-SO, School of Social Work Fribourg (HETS-FR), CH-1700 Fribourg, sandrine.haymoz@hefr.ch

**** University of Bern, Institut für Strafrecht und Kriminologie, CH-3012 Bern, anna.isenhardt@ krim.unibe.ch

1 The Swiss National Science Foundation funded this research (Grant no: 165760)
} 
While the ideology of the Radical Left was mainly influenced by Marxism and Communism in the post-war era until the late 1970s, the fall of the Berlin Wall and the dissolution of the Soviet Union in the 1980s led to a decline of Marxism / Communism and to an ideological diversification / renewal within the Radical Left.

The new militants of the Radical Left were socialized in the post-Soviet context. They acknowledged the failure of various left-wing revolutions. The revolutionary horizon is no longer at the center of their political project and they no longer have a clear society project. They fight against inequalities, but also for certain values such as democracy, freedom and equality and carry out militant actions in a more isolated and situational manner (Joshua 2015).

The ideological characteristics of the current Radical Left became therefore more heterogeneous and diversified. The distinction between the ideologically traditional and the modernized Left has been used for a long time to differentiate between the ideological currents of the Left and the Radical Left ${ }^{3}$ (Gallagher et al. 1995). While the traditional Left has materialistic values and mainly takes a position on the socio-economic cleavage with a redistributive focus, the new Left has postmaterialistic values (Inglehart 1977) and prefarably takes a position on the sociocultural cleavage with an increasing focus on the environmental issue. Whether with regard to socio-economic or to socio-cultural cleavages, the left-wing positioning can be more or less radical. Hence there are two types of the Radical Left: the new Radical Left focuses mainly on values by promoting libertarian and progressive ideals (postmaterialist Left) and the traditional Radical Left focuses mainly on economic issues by promoting egalitarian ideals (materialist Left). However, the rejection of capitalist values ${ }^{4}$ - which are considered responsible for social inequalities and alienation - is an important feature of both ideological currents (March 2011). The common denominator of the different ideological currents of the Radical Left is indeed Anti-Capitalism. The agreement between these different currents is more about their opposition to Capitalism and Neoliberalism than about having a common alternative project (March and Keith 2016). The ideology of the Radical Left is also characterized by strong opposition to the establishment, whether political or economic (Dunphy and Bale 2011). It also maintains a close link to certain social movements, such as anti-globalization, antifascist and pro-environmental. (Visser et al. 2014).

2 The authors would like to thank the two reviewers and the SJS Editorial Board for their constructive comments that improved the quality of the article, as well as. L. De Bernardini for his assistance in the production of the tables and Yukari and Gaël Curty for English proofreading. This distinction between the traditional Left and the new Left also applies to the Radical Left.

4 What distinguishes the Radical Left (both the traditional and the new Radical Left) from the moderate Left is the degree of this rejection of capitalist values. While the moderate left considers that Capitalism is reformable, the Radical Left rejects capitalist values in an absolute way. 
Given the relative diversity of ideologies among the Radical Left, the question arises as to what extent the various determinants ${ }^{5}$ of support for the Radical Left's ideologies have the same importance in relation to the ideological current. This article aims to answer this question by analyzing the determinants of support for the Radical Left ideologies on the individual and school class levels among youth in Switzerland. The contribution of the article is twofold: first, it will contribute to a better understanding of the support for the Radical Left ideologies among youth, an underdeveloped subject in the specialized literature; second, it will also contribute to explore the impact of the school context regarding adherence to the ideologies of the Radical Left. The literature on youth and politics has highlighted the importance of the impact of the school context concerning political socialization, but there is no contribution on political orientation. This article aims to fill this gap by analyzing the influence of different aspects of the school context on adherence to the ideologies of the Radical Left.

\section{Literature Review}

Compared to the abundant literature on Radical Right ideologies, little is known about the support for Radical Left ideologies in Europe. In the domain of political science, two kinds of studies exist: One concerning individual factors (Bowyer and Vail 2011; Ramiro 2016; Gomez et al. 2016; Charalambous and Lamprianou 2017) and the other concerning national factors on political positioning (March 2011; March and Rommerskirchen 2015). Only one of these (Visser et al. 2014) combines the analysis of both factors (individual and national), but the analysis focuses on the right-left positioning and not on voting for a Radical Left party.

With regard to the first kind of studies (individual factors), some of them concern only one country and the others cover several European countries. The research of Bowyer and Vail (2011) falls into the first category. It analyzes the rising electoral support for «Die Linke» in Germany. Results of this analysis show that this support is not only based on ideological radicalism and economic pessimism, but also on political attitudes concerning the distribution of wealth. Studies of Ramiro (2016), Gomez et al. (2016) and Charalambous and Lamprianou (2017) belong to the second category and analyze the support for the Radical Left parties in Western Europe. Ramiro (2016) analyzes the effect of key socio-demographic and attitudinal individual-level variables on the Radical Left vote. Results of his analysis show that both factors matter. Concerning social background factors, results show that belonging to the working class, being part of a union and living in a large urban area

5 By determinants we mean the factors that explain the adherence to the ideologies of the Radical Left. Explanatory factors on the individual level and the level of the school class will be studied in this article. 
all promote the support for the Radical Left parties. With regards to the attitudinal factors, the results highlight that lack of religious identification, dissatisfaction with democracy and a negative opinion of the EU membership all increase the probability of voting for a Radical Left party. Gomez et al. (2016) study the socio-demographic and attitudinal differences between the voter of traditional Radical Left parties and of New Left parties in Europe. Their findings show no differences between these two groups regarding gender, age, subjective social class belongings, union membership and degree of urbanization. However, a higher proportion of New Left supporters are highly educated and non-religious compared to the traditional Left ones. Furthermore, voters of the New Left are ideologically slightly more moderate, less eurosceptic and more dissatisfied with democracy. Charalambous and Lamprianou (2017) compare the socio-demographic and attitudinal characteristics of supporters of Radical Left parties with those of supporters of Socio-Democratic and Green parties. Their findings show that supporters of Radical Left parties are less educated and older than supporters of Green parties, but show no differences concerning gender and religion. Supporters of Radical Left parties exhibit more political distrust than supporters of Socio-Democratic parties and attribute less significance to a pro-environmental position than supporters of green parties. Overall, their results suggest that political conflicts within the Left are rooted in ideological oppositions and have little to do with structural categories.

As for the second group of studies (national factors), March analyzes the electoral success of the Radical Left parties in Europe (March 2011; March and Rommerskirchen 2015). His analysis shows, among others, that this electoral success depends on past party success, level of unemployment, Euroscepticism and anti-globalization attitudes. Visser et al. (2014) for their part, analyze the support for Radical Left ideologies in 32 European countries. Their results show that less income inequality within a country and a legacy of an authoritarian regime led to an increasing support for Radical Left ideology. They also illustrate that the Radical Left ideology is more often supported by unemployed people and those with a lower income. According to these results, Switzerland is unlikely to provide contextual conditions that are conducive to high levels of support for Radical Left ideology. Nevertheless, it was decided to work on the case of Switzerland, which can be considered as an ambitious endeavor.

The existing research on the Radical Left ideologies focuses on adults and analyzes support for these ideologies through their voting behavior. Given that some young people are not able to vote because of their age, it is not even possible to analyze their support for the Radical Left ideologies through their voting behavior. In addition, studies on young people seem to suggest that voting, elections and more generally formal channels are not the best way to study their political participations (Henn and Foard 2012; Henn et al. 2005). Voter turnout is lower for young people and they prefer less formal forms of political participation like demonstrations, boy- 
cotts and direct action (Henn and Foard 2012). For all these reasons, voting does not seem to be the best way to analyze youth support for Radical Left ideologies. In this case, ideological support should be measured directly. That is why this article aims to analyze the support of youth for different ideological dimensions of the Radical Left. It will examine whether the same determinants (both at the individual and classroom levels) equally contribute to three ideologies of the Radical Left: Anti-Capitalism, Communism / Anarchism and No Border ideology. Rejection of Capitalism as a system is a core principle of the Radical Left (Dunphy 2004), and it is also the common denominator of various currents of the Radical Left (March 2011). Communism and Anarchism are still important ideological currents of the Radical Left (March 2011) despite a decrease in numbers. Both can be considered as good representatives of the traditional Radical Left. No Border ideology was chosen because it is representative of the New Radical Left's ideology, another important current of the Radical Left ideology (Gomez et al. 2016). Eventually, these three ideological dimensions make it possible to cover both specific and common aspects of the ideological currents of the Radical Left.

No Border ideology aims to challenge the sovereignty of nation-states to control the mobility of people through migration policies (Anderson et al. 2009). It seeks to re-politicise the legitimacy of immigration restrictions and distinctions between nationals and foreigners. No Border ideology has a twofold component, both pro-migrant and anti-capitalist (Walters 2006). According to this ideology, the nation-state produces and strengthens the relationships of dependence and power that migrants suffer. Borders create divisions / inequalities among people according to the status they receive from the nation-state (for example some temporary foreign workers do not have the right to change jobs or employers). The control of mobility is related to the creation and maintenance of a working class: The denial of citizenship rights to certain categories of migrants is a method of creating a corruptible and cheap labor force within capitalism (Anderson et al. 2009). The ideology of the New Radical Left is not only about defending the rights of migrants and minority rights in general, but also about defending identity and environmental issues. The choice to study New Radical Left from No Border ideology is therefore not completely appropriate. However, the migration issue is particularly important in the current Swiss political context and the results presented in the following sections are in line with other research on the ideology of the New Radical Left that takes a more comprehensive point of view over various aspects.

\section{Theories and Hypotheses}

Four assumptions are presented in this section. The first three focus on the determinants of adherence to radical-left ideologies at an individual level and the last 
one at the level of the school classroom. Where theoretically justified, the effect of the determinants will be differentiated according to the ideological dimensions of the Radical Left.

The first hypothesis focuses on the role of socio-economic status and is related to Group-interest theory. "Group-interest theory states that individuals support ideologies that are mostly in the interest of the groups to which they belong" (Visser et al. 2014, 542). The role of group membership in ideological support is important. A classical thesis in political science is that political cleavages reflect social structures (Lipset and Rokkan 1967). In particular, class struggle between manual workers and the upper classes is seen as a major determinant of political cleavages (Nieuwbeerta 1995). According to this thesis, left wing ideologies are traditionally supported by the working class because it is in their interest. More generally, people in precarious socio-economic situations might tend to support radical social change, because they are dissatisfied with the way the system works, or because they are frustrated and helpless (Visser et al. 2014). The socio-economic situation of young people is not yet determined. Most are studying and are not working yet. Nevertheless, it is possible to locate them in the social structure (and determine if their socio-economic situation is more or less favorable) through the type of study/training they are conducting and their subjective perceptions of relative deprivation. Following this argument, we assume that young people in precarious socio-economic situations are more likely to support Radical Left ideologies than young people in good socio-economic situations. Given that the traditional Radical Left focuses more on the issues of economic redistribution than the new Radical Left (March and Keith 2016), we postulate that this effect of the socio-economic situation is stronger in the case of Communism / Anarchism and Anti-Capitalism than in the case of the No Border ideology (Hypothesis 1).

The second hypothesis deals with criticism and dissatisfaction with political institutions. Indeed, a broad set of attitudes linked with Radical Left ideologies is political dissatisfaction (Ramiro 2016). The way political representation works under capitalist conditions is criticized. Representative democracy is rejected as being driven by capitalist exploitation (Eley 2002). Moreover, the legitimacy of political institutions and participatory and deliberative aspects of democracy are seen as being diluted by Neoliberalism (Dunphy 2004; March and Mudde 2005; Charalambous and Lamprianou 2017). This political dissatisfaction can be expressed in different ways: by dissatisfaction with democracy, political deprivation, low political efficacy, distrust in democratic institutions and in the integrity and fairness of the juridical apparatus. Following this argument, we hypothesize that young people with a high level of political dissatisfaction are more likely to support Radical Left ideologies in general (Hypothesis 2).

The third hypothesis highlights the role of two fundamental values within the Radical Left: internationalism and anti-authoritarianism. A central characteristic of 
the Radical Left is its commitment to internationalism (March and Mudde 2005). This commitment is expressed in different ways: first by the search for cross-national networking and solidarity, second by considering that national and regional political issues have global causes (March and Mudde 2005), third by rejecting nationalist categories and the territorialization of the subjectivity (Anderson et al. 2009). Anti-authoritarianism is another feature of the Radical Left ideology (Marcuse 1979), especially within the new Radical Left. Within this ideological current, the revolution is above all cultural and aims at "liberation of the senses from the compulsion to perceive people and things merely as objects of exchange" (Marcuse 1979, 4). The questioning of authority and hierarchy and the demand for autonomy are part of this process of liberation. Following these arguments, we hypothesize that support for Radical Left ideologies is associated with a high level of internationalism and anti-authoritarianism. Since the new Radical Left focuses more on values and progressive ideals than the traditional Radical Left (March and Keith 2016), we postulate that anti-authoritarianism is more strongly associated with No Border ideology than with anti-capitalism and communism/anarchism (Hypothesis 3).

The fourth hypothesis focuses on the impact of the school context. School plays an important role in the political socialization of young people. Along with family socialization, school is considered the most important element in primary political socialization (Claes et al. 2012; Ekman 2013). Schools are involved in the political socialization process of young people at several levels:

, Through civic courses in which students are exposed to political messages through teachers and their peers (Ekman 2013).

, By the democratic climate within the classroom (Claes et al. 2012; Ekman 2013; Galais 2018). The school can be conceived as an opportunity to learn to live together with people from diverse social and cultural backgrounds. Adolescents live together outside their family environment and are confronted with a variety of opinions and values. In this regard, it is a way of experimenting democracy for young people. An open atmosphere for discussion in the classroom is a crucial element for the development of civic values such as political trust and tolerance (Claes et al. 2012).

, Via compositional aspects: The socioeconomic background of schools has an effect on the political socialization of students. For example, being surrounded by peers with well-educated parents is conducive to the development of political skills and knowledge (Ekman 2013).

In this article, we will focus in particular on compositional aspects. It is assumed that these aspects also have an impact on ideological and political orientations. Given the lack of literature on this subject, theses hypotheses are more exploratory than the previous ones. Three characteristics of the classroom will be studied: the dominant political orientation of the class and the presence of foreigners and eco- 
nomically disadvantaged students in the class, as well as their proportions. First, it is assumed that the dominant political orientation of the classroom has an impact on adherence to the ideologies of the Radical Left at the individual level. The more this dominant political orientation in the classroom leans to the left, the stronger the adherence to the ideologies of the Radical Left will be at an individual level by conforming to the majority. Second, it is assumed that proximity to students who have experienced specific life situations creates an awareness of social problems that can lead to repositioning their ideologies. Specifically, it is hypothesized that the proportion of foreign students in the classroom potentially impacts on adherence to the No Border ideology at an individual level. Furthermore, the proportion of economically disadvantaged students in the school class potentially impacts on adherence to anti-capitalism and communism/anarchism at an individual level (Hypothesis 4).

\section{Method}

\subsection{Survey and Sample}

The data analyzed in this article derive from a survey of young people in Switzerland on the theme of political radicalism (Manzoni et al. 2018). The survey was not representative of all young people in Switzerland. The participants were limited to students and conducted in 10 cantons of Switzerland only, but covered all linguistic regions. Students completed an online questionnaire in their classroom during one hour. The supervision of the completion of the questionnaires was carried out either by interviewers or by teachers in charge of the class. The participation in a survey was not obligatory and it was conducted anonymously.

The sampling procedure was carried out at four different levels: First, 10 Swiss cantons were selected out of 26 cantons; second, within these 10 cantons all secondary II schools ${ }^{6}$ were invited to participate in the survey; third, a number of classes were selected within each school participating in the survey; fourth, all students from the selected classes were invited to participate in the survey. Each step of this procedure is discussed in more detail below.

10 cantons of Switzerland (Basel-Land, Berne, Fribourg, Geneva, Lucerne, Solothurn, St. Gall, Ticino, Valais, and Zurich) were selected to participate in the survey. A combination of three criteria was used to select these 10 cantons: First, the selected cantons represent three linguistic regions of Switzerland (German-speaking, French-speaking and Italian-speaking); second, these cantons cover the rural and

6 In Switzerland, all schools that are accessible after mandatory schooling are considered as Secondary II schools. There are four types of secondary II schools: high school, technical secondary school, vocational school and transitional school. Given that the average age at the end of mandatory schooling in Switzerland is 15 years and that secondary II schools last 3 or 4 years, the average age of students in these schools is between 15 and 19 years. 
Table 1 (Non-)response rates at the school, classroom and student level

\begin{tabular}{|c|c|c|c|c|c|c|c|c|c|}
\hline \multirow[t]{2}{*}{ Canton } & \multirow{2}{*}{$\begin{array}{c}\text { School } \\
\text { level } \\
\text { Asked for } \\
\text { partici- } \\
\text { pation }\end{array}$} & \multicolumn{4}{|c|}{ School class-level } & \multicolumn{4}{|c|}{ Student level } \\
\hline & & $\begin{array}{l}\text { Partici- } \\
\text { pated }\end{array}$ & $\begin{array}{c}\text { Response } \\
\text { rate } \\
(\%)\end{array}$ & $\begin{array}{l}\text { Asked for } \\
\text { partici- } \\
\text { pation* }\end{array}$ & $\begin{array}{c}\text { Partici- } \\
\text { pated }\end{array}$ & $\begin{array}{c}\text { Response } \\
\text { rate } \\
(\%)\end{array}$ & $\begin{array}{l}\text { Asked for } \\
\text { partici- } \\
\text { pation }\end{array}$ & $\begin{array}{l}\text { Partici- } \\
\text { pated }\end{array}$ & $\begin{array}{c}\text { Response } \\
\text { rate } \\
(\%)\end{array}$ \\
\hline Basel-Land & 13 & 9 & 69 & 74 & 65 & 88 & 1069 & 939 & 88 \\
\hline Berne & 30 & 11 & 37 & 68 & 50 & 74 & 880 & 770 & 88 \\
\hline Fribourg & 11 & 11 & 100 & 81 & 75 & 93 & 1116 & 997 & 89 \\
\hline Geneva & 29 & 22 & 76 & 57 & 52 & 91 & 875 & 768 & 88 \\
\hline Lucerne & 18 & 2 & 11 & 20 & 10 & 50 & 174 & 153 & 88 \\
\hline Solothurn & 4 & 4 & 100 & 42 & 29 & 69 & 515 & 476 & 92 \\
\hline St.Gall & 29 & 15 & 52 & 82 & 56 & 68 & 931 & 848 & 91 \\
\hline Ticino & 20 & 18 & 90 & 81 & 71 & 88 & 880 & 766 & 87 \\
\hline Valais & 15 & 13 & 87 & 119 & 96 & 81 & 1524 & 1400 & 92 \\
\hline Zurich & 63 & 18 & 29 & 98 & 91 & 93 & 1329 & 1200 & 90 \\
\hline Total & 232 & 123 & 53 & 722 & 595 & 82 & 9293 & 8317 & 89 \\
\hline
\end{tabular}

*Note: for the cantons of Basel-Land, Fribourg, Lucerne, Solothurn, Ticino, Valais and Zurich one class out of two has been selected; for the cantons of Berne and St.Gall, one class out of three has been selected; for the canton of Geneva, a limit of about 50 classes has been decided by the Department of Public Education.

urban regions of Switzerland in a balanced way; finally, cantons with a high proportion of Muslims were selected because the survey also examined Islamist radicalism, which primarily affects Muslim youths. These 10 cantons at least partially reflect the diversity of Switzerland.

For each canton that participated in the survey, a list of all secondary schools in the canton was obtained from the departments of public education ${ }^{7}$. In total, there are 232 secondary II schools in the 10 cantons. All these schools were invited to participate in the survey in the 10 cantons. 123 schools agreed to participate $(53 \%)$. The main reasons given by the school directors to refuse participating in the survey are the following: The school curriculum is already full and they do not want to disrupt it; participation in other surveys is already taking a long time.

For each school which participates in a survey $(\mathrm{N}=123)$, a random sample of second year classes ${ }^{8}$ was drawn from the class lists provided by the schools. Depending on the canton, one class out of two or one class out of three was randomly selected. In some cases, the sample was limited by decision of the department of public education (which is the case for the Canton of Geneva, which limited the number of

7 With the exception of the canton of Lucerne, for which only vocational schools agreed to participate in the survey.

8 The choice of second year classes is justified by the average age of the students in these classes (1617 years old). By the end of adolescence, political orientation is already relatively well established and stable. 
Table 2 Return statistics by school type

\begin{tabular}{|c|c|c|c|c|c|c|c|c|c|c|}
\hline \multirow[t]{2}{*}{ Level } & \multicolumn{2}{|c|}{ Total } & \multicolumn{2}{|c|}{$\begin{array}{l}\text { Vocational } \\
\text { school }\end{array}$} & \multicolumn{2}{|c|}{$\begin{array}{l}\text { Transitional } \\
\text { education }\end{array}$} & \multicolumn{2}{|c|}{ High school } & \multicolumn{2}{|c|}{$\begin{array}{l}\text { Technical } \\
\text { secondary } \\
\text { school }\end{array}$} \\
\hline & $\begin{array}{l}\text { invited } \\
(100 \%)\end{array}$ & $\begin{array}{l}\text { partici- } \\
\text { pating }\end{array}$ & $\begin{array}{l}\text { invited } \\
(100 \%)\end{array}$ & $\begin{array}{l}\text { partici- } \\
\text { pating }\end{array}$ & invited & $\begin{array}{l}\text { partici- } \\
\text { pating }\end{array}$ & $\begin{array}{l}\text { invited } \\
(100 \%)\end{array}$ & $\begin{array}{l}\text { partici- } \\
\text { pating }\end{array}$ & $\begin{array}{l}\text { invited } \\
(100 \%)\end{array}$ & $\begin{array}{l}\text { partici- } \\
\text { pating }\end{array}$ \\
\hline Schools & 232 & $\begin{array}{r}123 \\
(53 \%)\end{array}$ & 120 & $\begin{array}{r}61 \\
(51 \%)\end{array}$ & 15 & $\begin{array}{r}11 \\
(73 \%)\end{array}$ & 82 & $\begin{array}{r}41 \\
(50 \%)\end{array}$ & 15 & $\begin{array}{r}10 \\
(67 \%)\end{array}$ \\
\hline $\begin{array}{l}\text { Classes in } \\
\text { participating schools }\end{array}$ & 722 & $\begin{array}{r}595 \\
(82 \%)\end{array}$ & 446 & $\begin{array}{r}352 \\
(79 \%)\end{array}$ & 76 & $\begin{array}{r}61 \\
(80 \%)\end{array}$ & 138 & $\begin{array}{r}122 \\
(88 \%)\end{array}$ & 62 & $\begin{array}{r}60 \\
(97 \%)\end{array}$ \\
\hline $\begin{array}{l}\text { Students in } \\
\text { participating classes }\end{array}$ & 9293 & $\begin{array}{r}8317 \\
(89 \%)\end{array}$ & 4916 & $\begin{array}{r}4449 \\
(90 \%)\end{array}$ & 884 & $\begin{array}{r}770 \\
(87 \%)\end{array}$ & 2490 & $\begin{array}{r}2197 \\
(88 \%)\end{array}$ & 1003 & $\begin{array}{r}901 \\
(90 \%)\end{array}$ \\
\hline $\begin{array}{l}\text { Youth coverage } \\
\text { estimated at the } \\
\text { individual level }\end{array}$ & & $39.1 \%$ & & $36.3 \%$ & & $51.3 \%$ & & $39.0 \%$ & & $58.0 \%$ \\
\hline
\end{tabular}

Source: Own data

classes that could be invited to participate in the questionnaire to 50). In total, 722 classes $^{9}$ were randomly selected from the 10 cantons. Out of these 722 classes, 127 classes refused to participate in the survey for various reasons (the planned time for the completion of the questionnaires falls during periods of examination or school exchanges for example). A total of 595 classes participated in the survey $(82.4 \%)$.

On 9293 students in these 595 classes, 8317 students participated in the survey $(89.5 \%) .10 .5 \%$ of the students who were invited to participate in the survey refused to participate for unknown reasons (these reasons were not systematically collected by the people in charge of supervising the completion of the questionnaires). However, it should be noted that the parents of the students could refuse child's participation in the survey, which explains the reason of some of the refusals. Since the sampling procedure to reach students is conducted at schools, it is not possible to calculate the total response rate at the individual level. Nevertheless, based on the assumption that the non-participating classes do not systematically differ from the participating classes in terms of the number of students, it is possible to say something about the number of young people reached compared to the population of youth. This youth coverage is $39.1 \%$ for the total sample.

According to Table 2, the non-response rate at school level varies according to the type of school: It is higher in vocational schools and high schools than in other schools. At the classroom level, the non-response rate is higher in vocational and transitional schools than in other schools. At the individual level, the non-response

9 Since the class selection rate varies according to the canton and in some cases we did not obtain a list of all the classes, it is difficult to precisely estimate the number of all the second year classes of the 123 schools participating in the survey. 
rate varies only slightly according to the type of school. In the end, these results imply that the vocational schools are under-represented in the sample, which is reflected by the lower youth coverage within this type of school (36\% whereas it is more than $50 \%$ for transitional education and technical secondary school and almost $40 \%$ for high school).

The final sample presented in this study consists of 6663 respondents. All usable data related to our variables are included in the analysis. Respondents whose answers were missing in variables analysis were excluded from the final sample.

\subsection{Measures}

The abolition of private property and the redistribution of wealth are central features of both communism and anarchism. Two items in the survey were used to determine adherence to these ideological objectives. The abolition of the state and self-government are central characteristics of anarchism and some factions of communism. Two items were also used in the survey to determine adherence to theses ideological objectives. Given the high value of Cronbach's alpha (0.7), they were combined into an average scale (communism/ anarchism).

Anti-capitalism is multidimensional. It is possible to differentiate three strands within the critique of capitalism (Jaeggi 2016): the first one focuses on the dysfunctions of capitalism, the second one on exploitation and the last one on alienation. Given the risk that functionalist critique and alienation critique may be misunderstood by young people because of their high level of abstraction, only Denunciation of exploitation was defined by several attitudes in the survey. First, critical attitudes towards multinationals and their responsibility in producing inequalities were determined by two items. Second, the accusation of the exploitation of the poor and the monopolization of urban spaces (anti-gentrification) by the capitalists gave rise to two other items. Given the high value of Cronbach's alpha (0.71), they were combined into an average scale (Anti-Capitalism).

As it was already mentioned in the literature review, No-Border ideology has a double component: pro-migrant and anti-capitalist (Walters 2006). Since anti-capitalism was already working with the specific scale, we decided to focus on the pro-migrant aspect to build the No Border scale in order to clearly distinguish the two scales. Adherence to No Border ideology was determined by two items in the survey, one emphasizing the rights of refugees, the other demanding to host more refugees. Given the relatively high correlation between these two items (0.47), they were combined into an average scale.

Table 3 presents the items used to operationalize the Radical Left's ideologies in the survey. Respondents were asked to rate these items on a 6-point scale ( 1 =strongly disagree; $6=$ strongly agree). An average of the scores on the different items composing each ideological dimension was then calculated. The combination 
Table 3

Items used to operationalize the ideological dimensions of the radical left $(N=6663)$

\begin{tabular}{|c|c|c|c|}
\hline & Items & Source & $\begin{array}{r}\text { Reliability } \\
(\text { r. respect. } \alpha) \\
\end{array}$ \\
\hline \multirow[t]{4}{*}{$\begin{array}{l}\text { Communism/ } \\
\text { anarchism }\end{array}$} & $\begin{array}{l}\text { We will really only be free, if the whole state } \\
\text { is abolished }\end{array}$ & Baier and Pfeiffer (2011) & .70 \\
\hline & $\begin{array}{l}\text { Property should be abolished; everything should } \\
\text { belong to everyone }\end{array}$ & Own development & \\
\hline & $\begin{array}{l}\text { We do not need a state and no parties; we are } \\
\text { the best at governing ourselves }\end{array}$ & Own development & \\
\hline & $\begin{array}{l}\text { Societies, in which all people have the same } \\
\text { (e. g. income, property) are better than the } \\
\text { Swiss society }\end{array}$ & Own development & \\
\hline \multirow[t]{2}{*}{ No Border } & $\begin{array}{l}\text { Switzerland should give refuge to more } \\
\text { refugees }\end{array}$ & Own development & .47 \\
\hline & $\begin{array}{l}\text { It is inhuman to deport people without valid } \\
\text { residence permits from Switzerland }\end{array}$ & Own development & \\
\hline \multirow[t]{4}{*}{ Anti-capitalism } & $\begin{array}{l}\text { The business leaders destroy the habitat of the } \\
\text { simple people in the cities }\end{array}$ & Own development & .71 \\
\hline & $\begin{array}{l}\text { The rich and powerful are exploiting the simple } \\
\text { people more and more }\end{array}$ & Baier and Pfeiffer (2011) & \\
\hline & $\begin{array}{l}\text { Nowadays, the major companies around the } \\
\text { world are leading the way }\end{array}$ & Own development & \\
\hline & $\begin{array}{l}\text { The major companies around the world are res- } \\
\text { ponsible for poverty and hunger in the world }\end{array}$ & Own development & \\
\hline
\end{tabular}

of the different items into an average scale is justified by the (relative) high values of Cronbach's alpha and correlation coefficients.

In order to test our first hypothesis, it was necessary to be able to determine the socio-economic situation of young people. It was decided to assess the socio-economic situation of young people through two criteria: the type of study/training they were conducting and their self-perception of relative deprivation. Four types of schools were identified for this study: vocational schools, transitional education, high schools and technical secondary schools. The question on relative deprivation was whether young people considered that they had ${ }^{10}$ more or less money in comparison with other young people. Three categories were distinguished: less money than others, the same as others or more money than others.

To test our second hypothesis, a set of scales ${ }^{11}$ were selected to determine the degree of political dissatisfaction. The first scale concerns satisfaction with democracy.

10 The survey concerns the respondent's situation and not his/ her family situation.

11 All scales presented are the result of a combination of items that respondents were asked to rate on a six-point scale ( 1 =strongly disagree; $6=$ strongly agree) except for the trust scale in institutions whose items had ten response modalities $(1=$ not at all confident; $10=$ totally confident $)$. 
This scale consists of two items (which are available in the appendix) that compare democracy with other systems of government and determine the level of satisfaction with democracy as it exists in Switzerland. The second is political deprivation. This scale contains two items to determine the extent to which young people believe they can influence politics. The third scale is external political efficacy and it contains two items to determine the proximity of Swiss politicians to the population. The fourth scale contains seven institutions. (Swiss politics, Swiss justice, The Swiss police, The Swiss army, Swiss companies and banks, The Swiss media, The Swiss authorities and public authorities) These are selected to operationalize trust in institutions. Finally, trust in the integrity of the justice system was examined through four questions to assess police integrity and fairness.

To test our third hypothesis, internationalism and anti-authoritarianism had to be operationalized. It was decided to operationalize internationalism negatively, through the absence of ethnic segregation and nationalism. Three items on ethnic segregation were aggregated to construct a scale. These items (available in the appendix) cover different dimensions of ethnic segregation: degree of openness to the mixing of cultures through inter-ethnic marriage, attachment to one's own culture and the propensity to develop inter-ethnic ties. Two items on nationalism were combined to form a scale. These items (also available in the appendix) cover different aspects of nationalism: the fact that the nation must belong to people who have resided there for generations and the fact that the nation's interests should be better promoted at the international level. Anti-authoritarianism was operationalized by the absence of authoritarianism. Four items (available in the appendix) were combined to form a scale. These items cover different aspects of authoritarianism, from submission to the elites, the need to punish criminals and the marginalized more severely, to the respect of the elderlies.

To understand the influence of different aspects of the classroom on adherence to radical left-wing ideologies and to test our fourth hypothesis, three variables on the classroom level were selected. First, the dominant political orientation of the class was operationalized by the classroom average on a ten-point left-right scale. Second, the presence of foreigners was operationalized by the percentage of Muslims ${ }^{12}$ in the classroom. And third, the presence of economically disadvantaged students was operationalized by the percentage of students in the classroom who consider themselves having not enough money ${ }^{13}$ to meet their needs.

The combination of the items in an average scale is justified each time by the high values of Cronbach's alpha or correlation coefficients. The list of items used to construct these scales and the source of these items are available in the appendix.

12 The choice to focus on Muslims is justified by their importance in political debates on foreigners in Switzerland and Europe.

13 As for relative deprivation the survey asks about the respondent's situation and not about his / her family situation. 
In addition to these variables to test the hypotheses made in the previous section, five control variables were included in the analyses: gender, age, city size, religious affiliation and linguistic region. The first two variables (gender and age) are standard control variables. The reason to select other three variables (city size, religious affiliation and linguistic region) is that they may have an impact on adherence to Radical Left ideologies according to the literature. Given the original Radical Left ideological antagonism towards religion (Ramiro 2016), it is expected that not identifying with any religion will increase the probability to support Radical Left ideologies. Since the majority of Radical Left voters are concentrated in urban areas (Ranger 1986), it is expected that living in large urban area will also increase this probability. With regard to linguistic regions, research on political cleavages in Switzerland highlights their importance (Trechsel 1995) and explains their possible influence on adherence to radical left-wing ideologies. In the following analyses, the size of the city is categorized into three: less than 5000 inhabitants, between 5000 and 20000 inhabitants and more than 20000 inhabitants. Four religious affiliations have been distinguished: Christian, Muslim, other religion and without religious affiliation. The linguistic region variable has three categories: German-speaking region, French-speaking region and Italian-speaking region.

\subsection{Statistical Analysis}

Regression models test the hypotheses presented in the previous section. The choice of multi-level regression models to test our hypotheses is explained by the nature of the data collected: The students interviewed are nested in school classes, which are by definition located in schools and cantons. Only two levels (individual and school class) are taken into account in the analyses of the following section - tests have been carried out and show that when school class level variability is considered (in addition to individual variability), the variabilities at school and cantonal level are no longer sufficient to justify additional levels in the regression models. Linear random intercept models were calculated to test our hypotheses. The method of maximum likelihood was used to estimate the parameters of the models. All calculations were performed with the STATA statistical package.

Several multi-level models were tested. First of all, for each dependent variable (communism/ anarchism, anti-capitalism and No-Border), a likelihood ratio test was performed to determine whether the multi-level empty model had a better goodness of fit than the linear empty model. In all three cases, multi-level models have a better goodness of fit than linear models, according to the likelihood ratio test ${ }^{14}$. These results provide a justification for the choice to use multi-level models. The independent variables were first introduced in blocks in the regression models each block of variables tests a hypothesis. A likelihood ratio test was then performed to determine whether adding the block of variables resulted in a better fit. For each

14 The intra-class correlation was also calculated for each model. It is about $10 \%$ for each model. 
block, the test result shows that adding the independent variables leads to a better fit of the model. Only final models with all independent variables to test the assumptions are presented. Multicollinearity has been tested, but no particularly high correlations between the independent variables have been detected (VIF-values are lower than 2).

\section{Results}

The first hypothesis is partially confirmed by the results of the multilevel linear regression models (see table 4). In line with this first hypothesis ( $\mathrm{H} 1)$, having less money than other increases the probability of adhering to all the ideologies of the Radical Left studied in this article. Nevertheless, contrary to our hypothesis, this effect of relative deprivation is not stronger for radical left-wing ideologies focusing on socio-economic cleavage (Communism/Anarchism and Anti-capitalism) than for those focusing on socio-cultural cleavage (No Border). Moreover, the role of the type of school is not as strong as expected: school with low-level education does not necessarily produce the most students adhering to radical left-wing ideologies. The type of school is probably not an excellent indicator of the socio-economic situation of students: In each type of school there are economically disadvantaged / advantaged students, even if there are more economically disadvantaged students in low-level schools. In brief, it can be concluded that students who consider themselves economically disadvantaged adhere the most to the ideologies of the Radical Left, but not the ones that focus specifically on the socio-economic oppositions.

The second hypothesis (H2) is also partially confirmed, particularly with regard to communism / anarchism and to a lesser extent with regard to anti-capitalism and No Border. In line with our second hypothesis, supporters of radical left ideologies suffer a higher level of political deprivation and they are less satisfied with democratic institutions. They are more critical of the integrity of the police than young people in general. On the other hand, contrary to our hypothesis, supporters of communism/anarchism and No Border ideology have a higher political efficacy and anti-capitalists are more satisfied with democracy than young people in general. In summary, it is the supporters of communism/anarchism who have the highest level of political dissatisfaction. Not only do they feel they have no influence on the government, but they are also dissatisfied with democracy and are the most distrustful of democratic institutions and the police. Supporters of anti-capitalism and No-Border ideology are less politically dissatisfied. They are not more dissatisfied with democracy than other young people (on the contrary, anti-capitalists are on average more satisfied with democracy than young people in general) but nevertheless have a certain distrust of the police and of democratic institutions (for anti-capitalists only). Our results therefore are in contradiction to those of Gomez et al. (2016) 
who showed that supporters of the Radical New Left were more dissatisfied with democracy. Among young Swiss people, it is the supporters of the ideologies of the traditional Radical Left who are the most politically dissatisfied.

The third hypothesis (H3) is confirmed for the No-Border ideology and to a lesser extent for anti-capitalism and communism/anarchism. In line with this hypothesis, authoritarianism is negatively linked to the ideologies of the Radical Left and particularly to No Border ideology. In accordance with this hypothesis, adherence to nationalism and ethnic segregation significantly reduces adherence to No Border ideology. What is surprising - and contradicts our third hypothesis - is that nationalism has a positive impact on adherence to communism / anarchism and anti-capitalism. This calls into question the internationalism of communism/anarchism and anti-capitalism (March and Mudde 2005) and highlights a certain heterogeneity between the different ideological currents of the Radical Left. While the Radical New Left represented by the supporters of No-Border ideology is clearly anti-nationalist and anti-authoritarian, the traditional Radical Left represented by the supporters of communism / anarchism (and to a lesser extent by anti-capitalists ${ }^{15}$ ) seems to be more conservative in this respect. These results must be confirmed in the adult population before being generalized.

Considering the role of the school class context (H4), the results highlight both an effect of the dominant political orientation and of the socio-economic and socio-cultural embedding of the classroom on the ideological positioning of young people. Concerning the first point, in line with our hypothesis, the results show that a right-wing political position at the classroom level reduces the chances of adhering to radical left-wing ideologies at the individual level. With respect to the second point, the results show that the higher the percentage of Muslims in the classroom, the lower the chances of adhering to anti-capitalism and No Border ideology at the individual level. They also show that a high proportion of economically disadvantaged students in the classroom has a negative effect on adherence to anti-capitalism and a positive effect on adherence to communism/anarchism at an individual level. These results on the impact of the school context should be taken with caution. They constitute a first exploration of the impact of the school context on adherence to radical left-wing ideologies and will need to be refined through further research. First, they highlight associations but not necessarily causality. Secondly, the mechanism behind the association is not always clear. For example, the influence of the proportion of Muslim students on individual ideological positioning is not easy to explain. Maybe, the presence of visibly foreign students in the classroom

15 As already mentioned in the introduction, anti-capitalism is the common ideological core of the different currents of the Radical Left, so there are representatives of both the traditional Radical Left and the New Radical Left within the anti-capitalist movement. The positive association between nationalism and anti-capitalism in our sample of young people suggests that representatives of the traditional left are in the majority among anti-capitalists. 
Table $4 \quad$ Multilevel linear regression models $\left(N_{\text {individuals }}=6663 ; N_{\text {classes }}=591\right)$; unstandardized coefficients are presented

\begin{tabular}{|c|c|c|c|}
\hline \multirow[t]{2}{*}{ Independent variables } & \multicolumn{3}{|c|}{ Fixed effects } \\
\hline & Communism & Anti-capitalism & No border \\
\hline \multicolumn{4}{|l|}{ Socio-economic situation } \\
\hline School type: Technical Secondary School (ref = Vocational) & $0.09 *$ & 0.06 & $0.18^{* * *}$ \\
\hline School type: High School (ref = Vocational) & -0.01 & 0.02 & $0.31 * * *$ \\
\hline School type: Transitional Education (ref = Vocational) & $0.10^{*}$ & -0.03 & $0.14^{*}$ \\
\hline Relative deprivation: Less money than other $(r e f=$ more $)$ & $0.08^{* * *}$ & $0.20^{* * *}$ & 0.20 *** \\
\hline Relative deprivation: The same amount of money than other & $0.08^{* * *}$ & $0.06^{*}$ & $0.15^{* * *}$ \\
\hline \multicolumn{4}{|l|}{ Political dissatisfaction } \\
\hline High Political Deprivation & $0.08^{* * *}$ & $0.06^{* * *}$ & $0.03^{*}$ \\
\hline High External Political Efficacy & $0.05^{* * *}$ & $<0.01$ & $0.08^{* * *}$ \\
\hline High Satisfaction with democracy & $-0.17^{* * *}$ & $0.07^{* * *}$ & $<0.01$ \\
\hline High Trust in Institutions & $-0.06 * * *$ & $-0.09 * * *$ & $<0.01$ \\
\hline High Police Procedural Justice & $-0.17^{* * *}$ & $-0.18^{* * *}$ & $-0.14^{* * *}$ \\
\hline \multicolumn{4}{|l|}{ Nationalism, authoritarianism } \\
\hline High authoritarianism & $-0.05^{* * *}$ & $-0.05^{* * *}$ & $-0.15^{* * *}$ \\
\hline High Nationalism & $0.10^{* * *}$ & $0.08 * * *$ & $0.33^{* * *}$ \\
\hline High ethnic segregation & -0.02 & $<0.01$ & $-0.11 * * *$ \\
\hline \multicolumn{4}{|l|}{ Class level variables } \\
\hline Mean on the left-right scale & -0.02 & $-0.05^{* *}$ & $-0.13^{* * *}$ \\
\hline Percentage of economically disadvantaged students & $0.005^{* * *}$ & $-0.003 * *$ & $<0.001$ \\
\hline Percentage of Muslims students & $<0.001$ & $-0.004^{* *}$ & $-0.005^{* * *}$ \\
\hline \multicolumn{4}{|l|}{ Control variables } \\
\hline Age: 17 years old $(r e f=16)$ & -0.01 & 0.05 & $<0.01$ \\
\hline Age: 18 years old and more $(r e f=16)$ & -0.02 & $0.12^{* * *}$ & -0.03 \\
\hline Gender: Girls (ref=Boys) & $-0.06^{* *}$ & $-0.09 * *$ & $0.07^{*}$ \\
\hline City size: 5000 to 20000 inhabitants (ref=less than 5000 ) & $<0.01$ & $<0.01$ & 0.06 \\
\hline City size: more than 20000 inhabitants (ref=less than 5000) & 0.05 & $0.13^{* * *}$ & $0.16 * * *$ \\
\hline Region: French speaking part of Switzerland (ref=German) & 0.03 & $-0.14^{* * *}$ & -0.06 \\
\hline Region: Italian speaking part of Switzerland (ref=German) & 0.07 & 0.08 & $-0.19 * * *$ \\
\hline Religion: Christians (ref=without religious affiliation) & 0.01 & $-0.09 * * *$ & 0.03 \\
\hline Religion: Muslims (ref=without religious affiliation) & $0.24^{* * *}$ & $0.13^{* *}$ & $0.66^{* * *}$ \\
\hline Region: Other religions (ref=without religious affiliation) & $0.23^{* * *}$ & 0.06 & $0.29 * * *$ \\
\hline Constant & $3.40 * * *$ & $4.60 * * *$ & $5.20 * * *$ \\
\hline \multicolumn{4}{|l|}{ Random effects } \\
\hline Standard deviation (Standard error) & $0.13(0.02)$ & $0.14(0.02)$ & $0.14(0.02)$ \\
\hline \multicolumn{4}{|l|}{ Snijders/Boskers R-squared } \\
\hline$\%$ of variance explained at the individual level & 0.21 & 0.14 & 0.29 \\
\hline$\%$ of variance explained at the school class level & 0.45 & 0.23 & 0.54 \\
\hline
\end{tabular}

${ }^{*} p<0.05^{* *} p<0.01{ }^{* * *} p<0.001$ 
may encourage the activation of traditionalist thinking patterns through defense mechanisms. Further research is needed to test these hypotheses.

Concerning the role of control variables, the results show that, in line with the literature (Ranger 1986), living in a large city increases the probability of adherence to anti-capitalism and No Border ideology. They also show that adherence to the No Border ideology is lower in the Italian-speaking part of Switzerland, a region that faces significant wage dumping via Italian border workers. With regard to the role of religion, the results do not confirm that supporters of radical left ideologies have no religious affiliation (Ramiro 2016). They show that young Muslims and young people with non-Christian religious affiliation adhere just as much or more to the ideologies of the radical left as young people without religious affiliation.

The contribution of the article is twofold: First, it has highlighted the common and specific aspects in the determinants of adhesion to the different ideologies of the Radical Left; second, it has contributed to the study of the impact of the school context on ideological positioning by showing that certain characteristics of the school class have an effect on adherence to the ideologies of the Radical Left.

Regarding to the first point, the analyses showed that being economically and politically deprived, having a low level of trust in the police, a high anti-authoritarianism all increase the probability of adhering to the different ideologies of the Radical Left. These results show that radical left-wing ideologies particularly attract young people who feel deprived of their economic and political agency and who question the figures of authority, whether it is the police or the elderlies. Further research is needed to determine the extent to which these results can be generalized for the entire population. The analyses also showed that some characteristics of the supporters of the traditional Radical Left (represented by communism/ anarchism) were different from those of the supporters of the Radical New Left (represented by No-Border ideology) or even opposite. Supporters of the traditional Radical Left tend to be more politically dissatisfied and more conservative with regard to the socio-cultural cleavage than supporters of the Radical New Left. These results must be seen in relation to the division within the Radical Left between a more traditional, materialist faction that focuses on the redistribution of wealth and material resources and a post-materialist faction that focuses on minority rights and identity issues (March and Keith 2016). While the former mainly attracts disadvantaged, politically dissatisfied and relatively conservative young people concerning sociocultural issues, the latter attracts more privileged, less politically dissatisfied and more progressive young people concerning socio-cultural issues. Further research is needed to determine the extent to which young supporters of the traditional Radical 
Left share characteristics and political positions with those of the Radical Right, particularly on the socio-cultural divide.

In regard to the second point, the results suggest that several aspects of the school class context have an impact on the ideological positioning of young people. First, the results show that the dominant political orientation of the classroom influences the ideological positioning of students, probably through conformism towards the majority. Secondly, they highlight the role of the socio-economic and socio-cultural embedding of the classroom as to the ideological positioning of young people, even if the mechanism by which influence takes place is less clear. Since most research on radical left-wing ideologies has focused on individual determinants, these results on the role of the school class context (meso level) are important and allow a more comprehensive approach to the factors influencing the adherence to radical left-wing ideologies. Nevertheless, to better understand how school context influences students' ideological positioning, new research to explore the impact of social influences is needed.

Finally, there are a number of limitations in the results presented in this article. First, the items used to operationalize anti-capitalism and No-Border ideology arguably cannot differentiate between moderate left and radical left. Indeed, a young moderate left may agree with the items used to operationalize anti-capitalism and No-Border ideology. Second, as it was already mentioned before, analyses on the ideology of the New Left are partial and further analyses with a more complete operationalization are needed in order to better understand what distinguishes young supporters of the radical new left from young supporters of the traditional radical left. The results presented in this article are considered to be a first step on a topic which requires further research.

\section{References}

Anderson, Bridget, Nandita Sharma, and Cynthia Wright. 2009. Why No Borders? Refuge 26(2): 5-18.

Baier, Dirk, Christian Pfeiffer, Susanne Rabold, Julia Simonson, and Cathleen Kappes. 2010. Kinder und Jugendliche in Deutschland. Gewalterfahrungen, Integration, Medienkonsum. Forschungsbericht Nr. 109. Hannover: Kriminologisches Forschungsinstitut Niedersachsen.

Baier, Dirk, and Christian Pfeiffer. 2011. Jugendliche als Opfer und Täter von Gewalt in Berlin. Forschungsbericht 114. Hannover: Kriminologisches Forschungsinstitut Niedersachsen.

Beierlein, Constanze, Christoph J. Kemper, Anastassyia Kovaleva, and Beatrice Rammstedt. 2012. Ein Messinstrument zur Erfassung Politischer Kompetenz - und Einflussüberzeugungen. GESISWorking Papers 18. Leibniz-Institut für Sozialwissenschaften.

Beyerle, Michelle, Sarah Bütikofer, and Isabelle Stadelmann-Steffen. 2015. Ich und meine Schweiz: Befragung von 17-jährigen Jugendlichen in der Schweiz. Forschungsbericht Nr. 13/15. Eidgenössiche Kommission für Kinder- und Jugendfragen.

Bowyer, Benjamin T., and Mark I. Vail. 2011. Economic Insecurity, the Social Market Economy, and Support for the German Left. West European Politics 34(4): 683-705. 
Charalambous, Giorgos, and Iasonas Lamprianou. 2017. The (Non) Particularities of West European Radical Left Party Supporters: Comparing Left Party Families. European Political Science Review 9(3): 375-400.

Claes, Ellen, Marc Hooghe, and Sofie Marien. 2012. A Two-Year Panel Study Among Belgian Late Adolescents on the Impact of School Environment Characteristics on Political Trust. International Journal of Public Opinion Research 24(2): 208-224.

Decker, Oliver, and Elmar Brähler. 2006. Vom Rand zur Mitte. Rechtsextreme Einstellungen und ihre Einflussfaktoren in Deutschland. Berlin: Friedrich-Ebert-Stiftung.

Dunphy, Richard. 2004. Contesting Capitalism? Left Parties and European Integration. Manchester, NH: Manchester University Press.

Dunphy, Richard, and Tim Bale. 2011. The Radical Left in Coalition Government: Towards a Comparative Measurement of Success and Failure. Party Politics 17(4): 488-504.

Eley, Geoff. 2002. Forging Democracy: The History of the Left in Europe, 1850-2000. Oxford: Oxford University Press.

Ekman, Joakim. 2013. Schools, Democratic Socialization and Political Participation: Political Activity and Passivity among Swedish Youths. Nordidactica - Journal of Humanities and Social Science Education 1: 1-11.

Galais, Carol. 2018. How to Make Dutiful Citizens and Influence Turnout: The Effects of Family and School Dynamics on the Duty to Vote. Canadian Journal of Political Science 51(3): 599-617.

Gallagher, Michael, Michael Laver, and Peter Mair. 1995. Representative Government in Modern Europe: Institutions, Parties and Governments. Boston, MA: McGraw Hill.

Gomez, Raul, Laura Morales, and Luis Ramiro. 2016. Varieties of Radicalism: Examining the Diversity of Radical Left Parties and Voters in Western Europe. West European Politics 39(2): 351-379.

Henn, Matt, Mark Weinstein, and Sarah Forrest. 2005. Uninterested Youth? Young People's Attitudes towards Party Politics in Britain. Political Studies 53(3): 556-578.

Henn, Matt, and Nick Foard. 2012. Young People, Political Participation and Trust in Britain. Parliamentary Affairs 65(1): 47-67.

Inglehart, Ronald. 1977. The Silent Revolution: Changing Values and Political Styles among Western Publics. Princeton: Princeton University Press.

Jaeggi, Rahel. 2016. What (if Anything) is Wrong with Capitalism? Dysfunctionality, Exploitation and Alienation: Three Approaches to the Critique of Capitalism. Southern Journal of Philosophy 54(1): 44-65.

Joshua, Florence. 2015. Anticapitalistes : une sociologie historique de l'engagement. Paris : Editions la Découverte.

Lipset, Seymour M., and Stein Rokkan. 1967. Party Systems and Voter Alignments: Cross-National Perspectives. London: Collier-MacMillan.

Manzoni, Patrik, Dirk Baier, Sandrine Haymoz, Anna Isenhardt, Maria Kamenowski, and Cédric Jacot. 2018. Verbreitung extremistischer Einstellungen und Verhaltensweisen unter Jugendlichen in der Schweiz. Zurich: ZHAW Zürcher Hochschule für Angewandte Wissenschaften.

March, Luke. 2011. Radical Left Parties in Europe. Abingdon: Routledge.

March, Luke, and Cas Mudde. 2005. What's Left of the Radical Left? The European Radical Left after 1989: Decline and Mutation. Comparative European Politics 3(1): 23-49.

March, Luke, and Charlotte Rommerskirchen. 2015. Out of Left Field? Explaining the Variable Electoral Success of European Radical Left Parties. Party Politics 21(1): 40-53.

March, Luke, and Daniel Keith. 2016. Europe's Radical Left: From Marginality to the Mainstream? London: Rowman and Littlefield International.

Marcuse, Herbert. 1979. The Failure of the New Left? New German Critique 18: 3-11. 
Nieuwbeerta, Paul. 1995. The Democratic Class Struggle in Twenty Countries, 1945-1990. PhD Dissertation, Public Administration and Political Science, Radboud University, Netherlands.

Ramiro, Luis. 2016. Support for Radical Left Parties in Western Europe: Social Background, Ideology and Political Orientations. European Political Science Review 8(1): 1-23.

Ranger, Jean. 1986. Le déclin du parti communiste français. Revue française de science politique 36(1): 46-63.

Rippl, Susanne, Dirk Baier, Angela Kindervater, and Klaus Boehnke. 2005. Die EU-Osterweiterung als Mobilisierungsschub für Ethnozentrische Einstellungen? Zeitschrift für Soziologie 34(4): 288-310.

Trechsel, Alexandre H. 1995. Clivages en Suisse : analyse des impacts relatifs des clivages sur l'électorat suisse lors des élections fédérales. Etudes et recherches no 31. Université de Genève : département de science politique.

Visser, Mark, Marcel Lubbers, Gerbert Kraaykamp, and Eva Jaspers. 2014. Support for Radical Left Ideologies in Europe. European Journal of Political Research 53(3): 541-558.

Walters, William. 2006. No Border: Game With(out) Frontiers. Social Justice 33(1): 21-39. 


\section{Appendix}

Table A1 Items used to build the scales

\begin{tabular}{|c|c|c|}
\hline Variables & Items & Source \\
\hline \multirow[t]{2}{*}{ Political deprivation } & $\begin{array}{l}\text { Anyway, people like me have no influence on what } \\
\text { the government does }\end{array}$ & Rippl et al. 2005 \\
\hline & I find it useless to get involved politically & Rippl et al. 2005 \\
\hline \multirow[t]{2}{*}{$\begin{array}{l}\text { Political efficacy } \\
\text { (external) }\end{array}$} & $\begin{array}{l}\text { Swiss politicians try to maintain close contact } \\
\text { with the population }\end{array}$ & Beierlein et al. 2012 \\
\hline & $\begin{array}{l}\text { Swiss politicians are concerned about } \\
\text { what people think }\end{array}$ & Beierlein et al. 2012 \\
\hline \multirow[t]{2}{*}{$\begin{array}{l}\text { Satisfaction with } \\
\text { democracy }\end{array}$} & $\begin{array}{l}\text { Overall, I am satisfied with democracy as it exists } \\
\text { in Switzerland }\end{array}$ & Baier and Pfeiffer 2011 \\
\hline & Democrarcy is the best form of government & Eurobarometer \\
\hline \multirow[t]{7}{*}{ Trust in institutions } & Swiss politics & Beyerle et al. 2015 \\
\hline & Swiss justice & Beyerle et al. 2015 \\
\hline & The Swiss police & Beyerle et al. 2015 \\
\hline & The Swiss army & Beyerle et al. 2015 \\
\hline & Swiss companies and banks & Beyerle et al. 2015 \\
\hline & The Swiss media & Beyerle et al. 2015 \\
\hline & The Swiss authorities and public authorities & Beyerle et al. 2015 \\
\hline \multirow[t]{4}{*}{ Procedural Justice } & $\begin{array}{l}\text { The police treat some victims who file complaints } \\
\text { less than others because they belong to another } \\
\text { nationality }\end{array}$ & European Social Survey \\
\hline & In general, I find that the police behave correctly & European Social Survey \\
\hline & The police are corrupted & European Social Survey \\
\hline & $\begin{array}{l}\text { In general, I think the police understand how } \\
\text { young people think }\end{array}$ & European Social Survey \\
\hline \multirow[t]{4}{*}{ Authoritarianism } & $\begin{array}{l}\text { We should be grateful to the ruling elites who clearly } \\
\text { tell us what we should no do }\end{array}$ & Baier and Pfeiffer 2011 \\
\hline & Children should adapt their parents' ideas & Baier and Pfeiffer 2011 \\
\hline & Crimes should be punished more severely & Baier and Pfeiffer 2011 \\
\hline & $\begin{array}{l}\text { In order to preserve order and justice, more severe action } \\
\text { should be taken against the marginalized } \\
\text { (e.g. homeless and drug addicts) and troublemakers }\end{array}$ & Baier and Pfeiffer 2011 \\
\hline \multirow[t]{2}{*}{ Nationalism } & $\begin{array}{l}\text { Switzerland should belong only to the Swiss, } \\
\text { who have lived there for generations }\end{array}$ & Own development \\
\hline & $\begin{array}{l}\text { We should impose Switzerland's interests } \\
\text { abroad more strongly and energetically }\end{array}$ & Decker and Brähler 2006 \\
\hline \multirow[t]{3}{*}{ Ethnic segregation } & People of my nationality should only marry each other & Baier et al. 2010 \\
\hline & $\begin{array}{l}\text { People of my nationallity should no longer stay } \\
\text { between themselves }\end{array}$ & Baier et al. 2010 \\
\hline & $\begin{array}{l}\text { People of my nationality should be more attached to } \\
\text { their own culture }\end{array}$ & Baier et al. 2010 \\
\hline
\end{tabular}

